\title{
Gedanoleria eocenica - a new genus and species from Eocene Baltic amber (Diptera: Heleomyzidae), with notes on heleomyzid-like flies from African copal
}

\author{
Andrzej Józef WoźNICA * \\ Institute of Biology, Wrocław University of Environmental \& Life Sciences, \\ Kożuchowska 5b, 51-631 Wrocław, Poland
}

\begin{abstract}
A new genus and species of a handsome heleomyzid fly, Gedanoleria eocenica gen. nov., sp. nov. (Diptera: Heleomyzidae), is described from Baltic amber. The newly described genus is compared with similar extant and extinct genera. The heleomyzid-like flies described by MEUNIER from African copal are treated as nomina dubia. A checklist and a key to the genera of Heleomyzidae reported from fossil resins are also provided.
\end{abstract}

KEY WORDS: Heleomyzinae, Paleogene, succinite, African copal, taxonomy, fossils, key, checklist.

\section{INTRODUCTION}

Succinite or Baltic amber is the richest repository of fossil insects of all geological periods. So far, some 1250 Diptera species have been described from this material (SZADZIEWSKI et al. 2018). Even so, knowledge of the fauna of Eocene Baltic amber forests is still insufficient (only about $1 \%$ of extant species of dipterans). Therefore, studies of fossils, preserved as inclusions in amber, are important because they provide an additional scientific source for reconstructing the phylogeny and for understanding the present-day relationships of extant groups.

Among acalyptrate dipterans recorded in Baltic amber, Heleomyzidae or sun-flies are one of the richest families of flies (TSCHIRNHAUS \& HofFEINS 2009). Eight genera of Heleomyzidae have hitherto been recorded from Baltic amber (EvEnHUIS 1994, 2014,

\footnotetext{
${ }^{*}$ Corresponding author: andrzej.woznica@ upwr.edu.pl
} 
WOŹNICA \& PALACZYK 2005, WoźNICA 2006a, 2007), and another seven heleomyzid species identified on the basis of compressions or impressions have been described (EVENHUIS 1994). Most of them are generally in a bad condition and only partially preserved: as the descriptions are rather basic, the material requires re-examination.

Like currently recorded fossil species, the majority of extinct taxa represented a variety of habitat preferences. Moreover, only two genera - Suillia RoBINEAU-DESVOIDY, 1830 and Heteromyza FALLÉn, 1820 - are also known in the recent fauna. They mostly inhabit wooded areas, where their larvae develop in decaying animal or fungal debris, e.g. birds' nests or basidiomycete fungi. All the fossil heleomyzid genera described from Baltic amber are monotypic. The present study yielded a new genus and species in a piece of Baltic amber deposited in the HoFFEINS collection. It is described here within the subfamily Heleomyzinae sensu PAPP (1998) but is not categorized in any of the tribes proposed by MCALPINE (1985).

\section{MATERIAL AND METHODS}

The specimen described below was found among the Acalyptratae inclusions studied in the collection of Christel and Hans Werner HoffeINS (Hamburg, Germany). The inclusion is preserved in a polished piece of amber, yellowish in colour, and embedded in GTSpolyester resin. The photograph was taken with a Canon $600 \mathrm{~d}$ digital camera attached to a Nikon SMZ stereomicroscope, using computer graphic techniques (Corel Draw X6) and the CombineZP photo stacking method. Figs. 2-4 are based on digital drawings produced with the Corel Designer X6 program during the examination of the original specimen. The morphological terminology and abbreviations follow those proposed by CUMMING \& WOOD (2018) and WoźNICA (2003, 2006b). This inclusion from the HofFeINS Collection $(\mathrm{CCHH})$ will be deposited at the Senckenberg Deutsches Entomologisches Institut, Müncheberg, Germany (SDEI). The colours of the inclusions in Baltic amber described below are not important and have no diagnostic value, as they are not well preserved or were altered during the process of fossilization (SZADZIEWSKI 1988).

RESULTS

\section{Descriptions}

Class Insecta LiNNAEUS, 1758

Order Diptera LinNAEUS, 1758

Superfamily Sphaeroceroidea MACQUART, 1835 
Family Heleomyzidae WESTWOOD, 1840

Subfamily: Heleomyzinae WESTWOOD, 1840

\section{Gedanoleria gen. nov.}

Type species. Gedanoleria eocenica sp. nov.; present designation.

\section{Diagnosis}

Gedanoleria is readily distinguished among fossil and extant Heleomyzidae by the numerous dorsocentral setae (7), bare anepisternum, lack of scapular seta, one distinct proepimeral seta, and distinctly protruding cheek (see key). Female unknown.

\section{Etymology}

The generic name is a combination of Gedanum - the Latin appellation of Gdańsk - and the generic heleomyzid name Leria.

\section{Gedanoleria eocenica sp. nov.}

(Figs. 1-4)

\section{Diagnosis}

As for the genus.

Description. Body dark brown, with silver dusting and shiny (Fig. 1). Body length: ca $2.3 \mathrm{~mm}$ (without antennae).

\section{Head}

Head ratio ca 1.3 with distinctly protruding cheek (Fig. 2). One vibrissa present, peristomal setulae well developed and distinctly larger than the other situated behind the eye border, in two irregular rows. Eyes big and slightly oval. Cheek small and protruding at the apex, cheek-eye ratio $<0.2$. Face slightly darker than genal area. Palpus pale, rounded apically, hypostom with some short setulae on lower margin.

\section{Antenna}

Scape and pedicel dark, almost blackish. Scape bare, without setae, pedicel with single big apical seta anterodorsally. First flagellomere large, round and black (first-flagellomere to cheek ratio ca 3.0). Arista pubescent, shorter than height of head. Frons covered by 


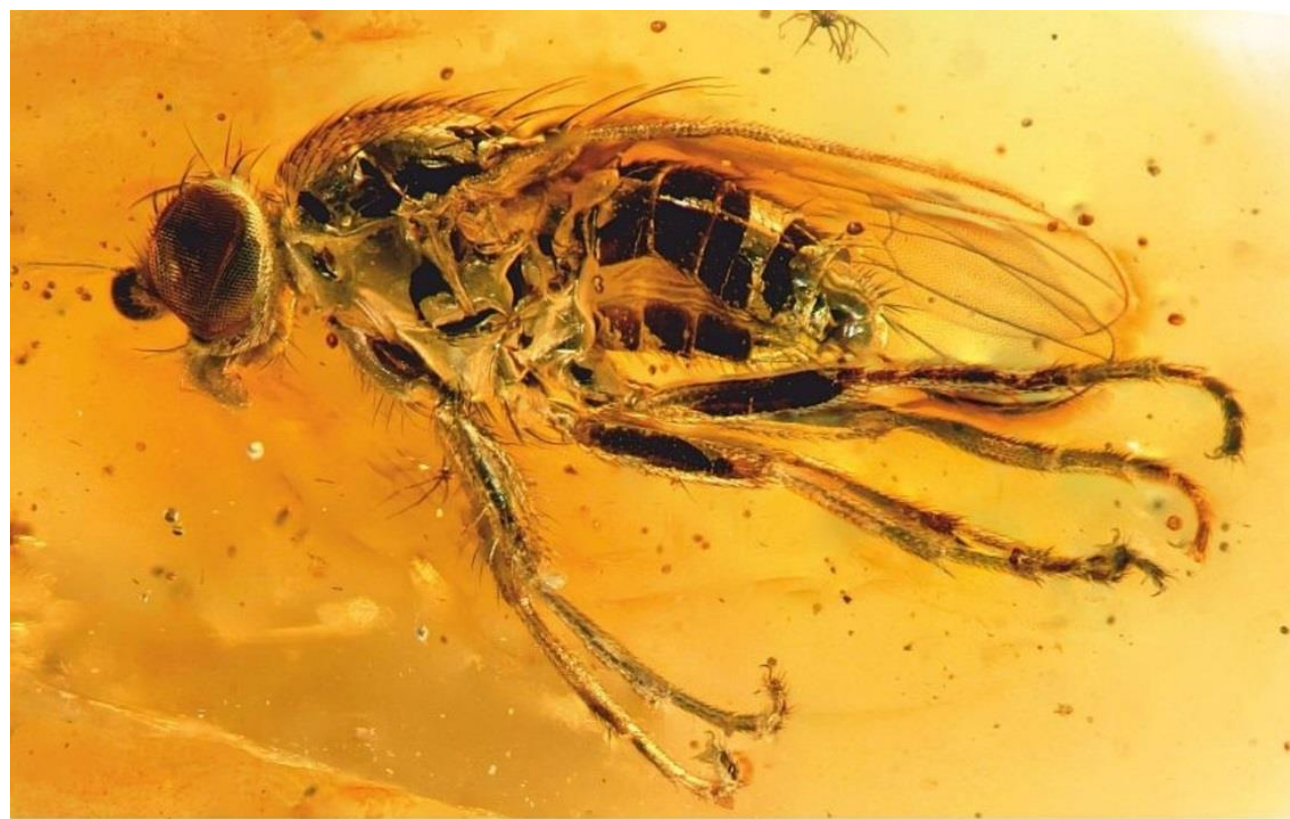

Fig. 1. Gedanoleria eocenica sp. nov., male in lateral view.

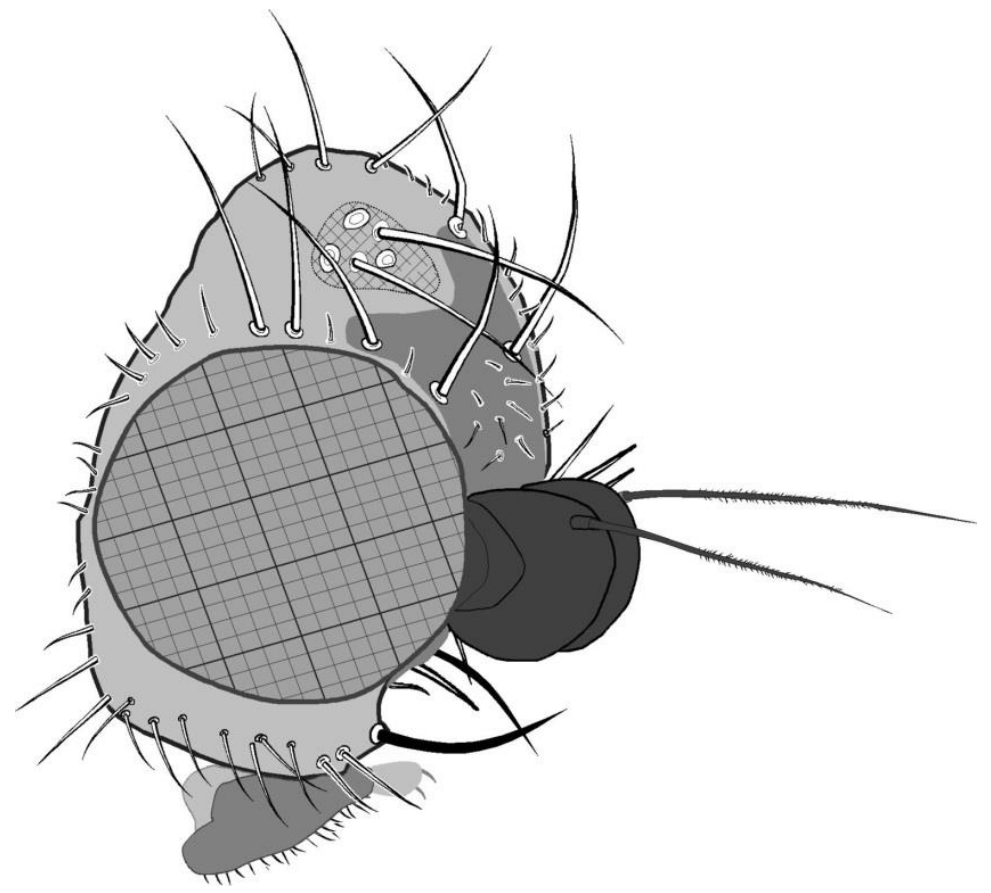

Fig. 2. Gedanoleria eocenica sp. nov., head in laterodorsal view. 
a few, small setulae, entirely dark, almost blackish-brown, except the eye-margins (Fig. 2). Frontal plate elongated, with two equal orbital setae. Distance between setae the same as that from anterior orbital seta to frontal margin (Fig. 2). A pair of strong ocellar setae, two well-developed vertical setae, postocellars medium sized and cruciate.

\section{Thorax}

Prosternum elongated and bare. Mesonotum chaetotaxy typical of Heleomyzinae, except for the number of dorsocentrals and acrostichals. One well-developed postpronotal, two notopleurals, one presutural, one supra-alar and two post-alar setae present. Mesonotum sparsely setulose, with seven pairs of dorsocentral setae; none of them arising from spots (Fig. 3): one/two of them in presutural area, 5 to6 behind suture. Postsutural

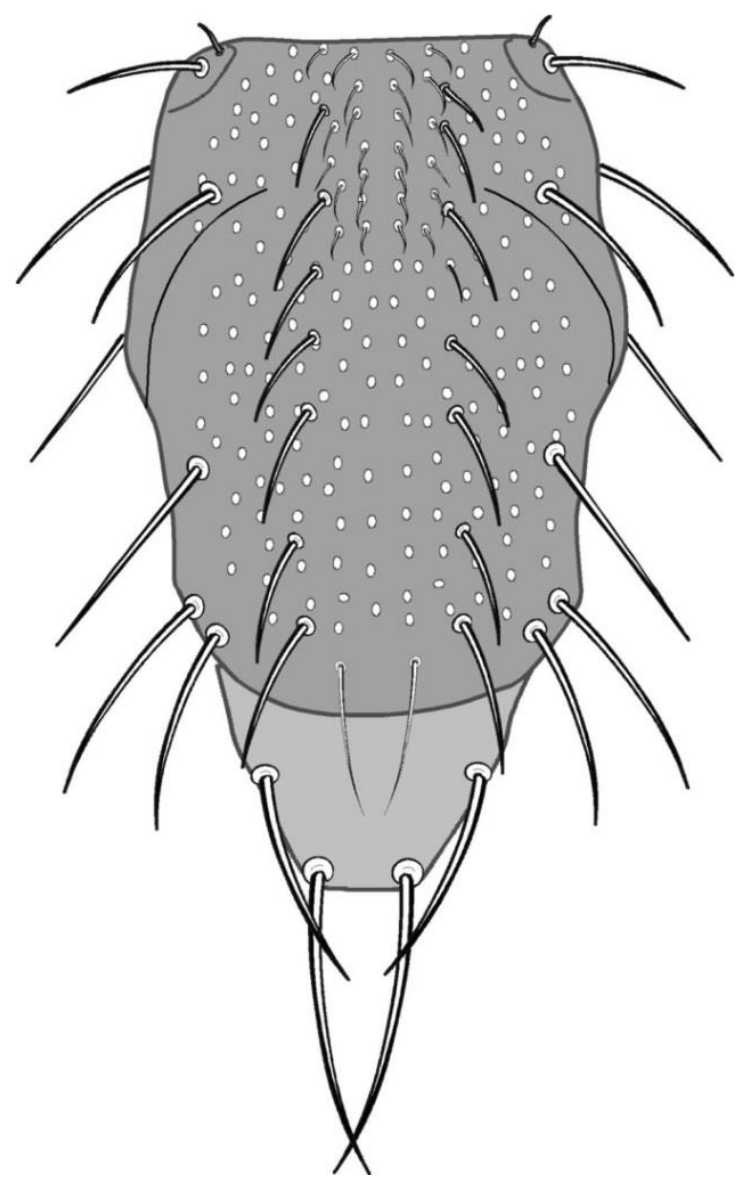

Fig. 3. Gedanoleria eocenica sp. nov., scheme of thoracic chaetotaxy in dorsal view. 
Postsutural dorsocentral setae relatively strong, especially last three distally. A pair of prescutellar setae are well developed. Scutellum slightly elongated, not pointed apically, dark and bare, except for two pairs of scutellars, the proximal pair shorter than the distal one. Acrostichals in four irregular rows. Proepisternum setulose with one well-developed seta (missing on left side). One proepimeral seta with any additional setae in anterior corner of anepimeron. Anepisternum and meron entirely bare. Katepisternum entirely bare, except for setulose margins between coxae. Two katepisternal setae, posterior one much longer (anterior about $1 / 3-1 / 2 \times$ posterior one) with a row of few setulae in front of them.

Wing (Fig. 4) longer than total length of body, ca $2.4 \mathrm{~mm}$, width ca $1.0 \mathrm{~mm}$. Wing membrane transparent, anal vein well developed. Costa with short, weak costal spines dorsally, especially anteriorly to subcostal break. Subcostal cell similar to that of nonOrbellia species, with subcostal vein ending before anterior cross-vein. Longitudinal veins pale, yellowish-brown. Cross-veins not darkened, r-m and dm-cu well developed. Medial vein ratio ca 1.45 (left wing). Haltere whitish, with an elongated and slightly sharpened knob at apex.

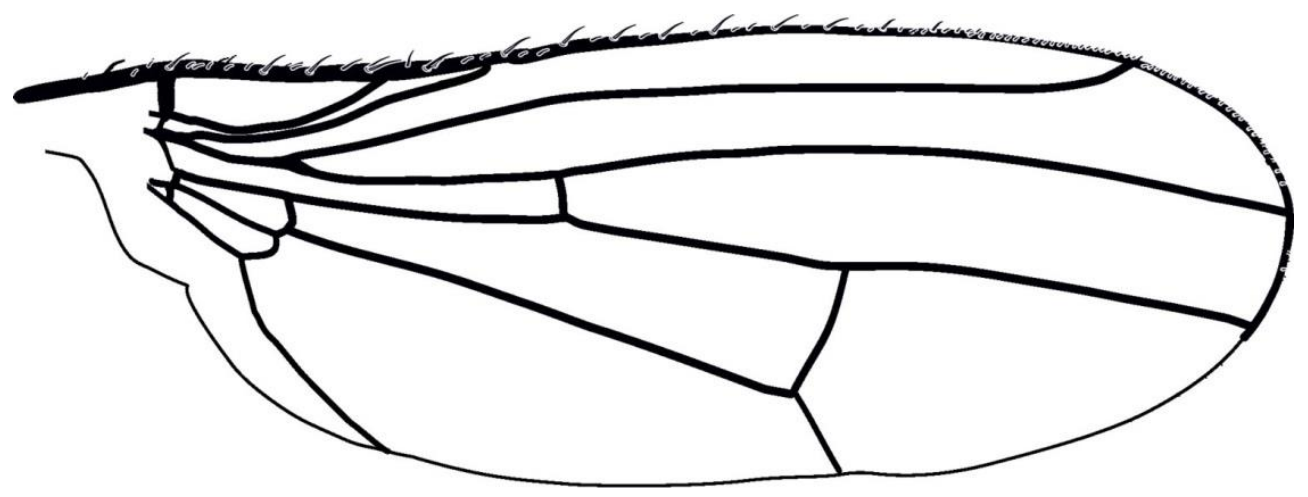

Fig. 4. Gedanoleria eocenica sp. nov., scheme of wing venation in lateral view.

Legs slender, mainly short setose. Fore femur with two rows of strong setae antero-, and posterodorsally. Mid femur with one row of setae well developed anterodorsally. Hind femur without dorsolateral setae. All tibiae short, setulose, each one with a single small preapical seta. Tarsomeres not darkened. First tarsomere of all tarsi much longer than second one (ca twice as long as second tarsomere). Claws much longer than small and whitish pulvilli. 


\section{Abdomen}

Abdominal segments dark brown. Segments I-VI well developed; first five symmetrical, rather short and sparsely setulose, with weak lateral marginal setae. Segment VI slightly asymmetrical, with distinctly longer setae in distal half. Epandrium brown, rather small and rounded, short and sparsely setulose. Cerci long haired.

\section{Type material}

Holotype, male: No. 1665-3 / Baltic Amber / Coll. Christel and Hans Werner HofFEINS II. Gedanoleria eocenica WoźNICA, 2019 gen. et sp. n. [M] (red). Inclusion embedded in polyester block $11.65 \times 10.65 \times 4.0 \mathrm{~mm}$.

Etymology. The specific epithet refers to the Eocene, the geological time of the species' origin.

\section{DISCUSSION}

The newly described genus is a typical representative of the subfamily Heleomyzinae in having the following characters: distinct preapical seta on all tibiae, wings with welldeveloped costal spines and anal vein reaching wing margin. It differs from all known fossil genera in having 7 pairs of dorsocentral setae. WOŹNICA (2006a) described the new genus Protoorbellia and mentioned the high variability in the number of dorsocentral setae in recent Orbellia species. According to GORODKOV's hypothesis (1972), the number of these setae in recent Heleomyzidae in all probability underwent oligomerization, which may now characterize the taxa included within Heleomyzini (GORODKOV 1984). The presence of a short arista and distinct proepimeral seta are plesiomorphic character states of the genus. The apomorphic characters are as follows: minute, hair-like acrostichals, and two big, equal orbital setae (as in recent Heleomyza species).

Checklist of Heleomyzidae described from fossilized tree resin (modified after EvenHUIS 1994)

Although Heleomyzid flies have often been included in lists of fossil taxa, only EVENHUIS (2014) and TSCHIRNHAUS \& HOFFEINS (2009) provided checklists of fossil heleomyzid flies. Unfortunately, the former author did not include the taxa described by WoźNICA $(2005,2006 a, 2007)$, while the latter mentioned those only taxa described from amber. Prior to the present investigation, 12 species were classified within two subfamilies of Heleomyzidae (EvenHuis 2014) and reported as extinct, known only from fossilized resin. 
I have removed from the family other heleomyzid flies found as inclusions in copal from Accra, Zanzibar and Madagascar, described by Meunier, and treat them as nomina dubia. With just MEUNIER's original drawings and descriptions to hand, there is no basis upon which to determine which genus or even family they represent. According to the original description, Helomyza humilis MEUNIER, 1919 does not belong to Heleomyzidae. The elongated antennal segments (MEUNIER 1910: Fig. 7) are not of the heleomyzid-shape type; rather, they resemble those in Sciomyzidae. Also, neither Leria species (MEUNIER 1910: Figs 9, 12) are typical heleomyzid flies, so their classification in the genus Heleomyza FALLÉN, 1910 (EVENHUIS 1994), a typical Holarctic taxon, is unjustifiable: they are very small flies, with a body length of no more than $2 \mathrm{~mm}$ and a head chaetotaxy of the non-Sphaeroceroid type. According to the sketchy original description, the genus Leriella MEUNIER, 1908 resembles representatives of various Acalyptratae families. Re-examination of the types of these species would shed new light on their taxonomic position. Presumably, they will be removed from Heleomyzidae and transferred to other families of Diptera.

Subfamily Heleomyzinae

Genus Balticoleria WoźNICA, 2007: 84.

Balticoleria michaeli WoŹNICA, 2007: 85. Baltic amber, Eocene, 56-33.9 Ma (WoŹNICA 2007, TSCHIRNHAUS \& HOFFEINS 2009).

Genus Chaetohelomyza HENNIG, 1965: 148.

Chaetohelomyza electrica HENNIG, 1965. Baltic amber, Eocene, 56-33.9 Ma (HENNIG 1965, TSCHIRNHAUS \& HOFFEINS 2009).

Genus Electroleria HENNIG, 1965: 150.

Electroleria alacris (MEUNIER, 1904: 25). Baltic amber, Bitterfeld amber, Eocene, 56-33.9 Ma (HENNIG 1965, 1969, TsCHIRNHAUS \& HoFFEINS 2009).

Genus Gedanoleria WoźNICA, 2019: 397.

Gedanoleria eocenica WoźNICA, 2019. Baltic amber, Eocene, 56-33.9 Ma (present paper).

Genus Heteromyza FALLÉN, 1820a: 1.

Heteromyza dubia MeUNIER, 1904: 25. Baltic amber, Eocene, 56-33.9 Ma, Bitterfeld (MEUNIER 1904, HENNIG 1965, 1969, TSCHIRNHAUS \& HOFFEINS 2009) 
WOŹNICA A.J.: Gedanoleria eocenica gen. nov. spec. nov. from Eocene Baltic amber 403

Genus Paleoheleomyza WoŹNICA et PALACZYK 2005: 374.

Paleoheleomyza kotejai WoźNICA et PALACZYK 2005: 374. Baltic amber, Eocene, 56-33.9 Ma (WoŹNICA \& PALACZYK 2005, TSCHIRNHAUS \& HOFFEINS 2009).

Genus Protoorbellia WoźnICA 2006: 148.

Protoorbellia hoffeinsorum WoźNICA 2006: 148. Baltic amber, Eocene, 56-33.9 Ma (WoŹNICA 2006, TSCHIRNHAUS \& HOFFEINS 2009).

Subfamily Suilliinae

Genus Protosuillia HeNNIG, 1965: 145.

Protosuillia media (MeunIER, 1904: 24): Baltic amber, Eocene, 56-33.9 Ma (HeNNIG 1965, 1969, TSCHIRNHAUS \& HOFFEINS 2009).

Genus Suillia RoBINEAU-DeSVOIDY, 1830: 642.

Suillia major (MEUNIER, 1904: 22). Baltic amber, Bitterfeld amber, Eocene, 56-33.9 Ma, (HENNIG 1965, 1969, TSCHIRNHAUS \& HOFFEINS 2009).

\section{Nomina dubia}

Helomyza humilis MeUnIER, 1910: 143. Afrotropical region: Tanzania (Zanzibar copal, Holocene, <1.6 Ma).

Leria insatiabilis MEUNIER, 1910: 145. Afrotropical region: Ghana (Accra copal, Holocene, <1.6 Ma).)

Leria insaturabilis MEUNIER, 1910: 144. Afrotropical region: Madagascar (Madagascan copal, Holocene <1.6 Ma).

Leriella crassifemorata MEUNIER, 1908: 6. Afrotropical region: Tanzania (Zanzibar copal, Holocene, <1.6 Ma).

Key to the identification of genera of the family Heleomyzidae reported from ambers

10 years ago, an amended key of HENNIG's Acalyptratae found in Baltic amber was presented by TSCHIRNHAUS \& HOFFEINS (2009). They proposed a key which shows the high biodiversity of acalyptrate flies, with many species mentioned there as sp. nov. (species nova) that have never been described. The most valuable aspect of this key was to show the great richness and diversity of chaetotaxy of the fossil Acalyptratae flies, as is also the case in recent fauna. The key presented here includes only formally described heleomyzid genera. 
1. Head with orbital plate oblique, medially directed anteriorly, clearly separated from eye margin. Thorax without postpronotal seta; Suilliinae.

-. Head with orbital plate not oblique, not medially directed anteriorly, running parallel to eye margin. Thorax with postpronotal seta; Heleomyzinae.

2. One orbital seta only present. Suillia RoBINEAU-DESVOIDY, 1830.

-. Two orbital setae present. Protosuillia HeNNIG, 1965.

3. Presutural dorsocentral setae absent.

-. Presutural dorsocentral setae present. ........................................................................ 7.

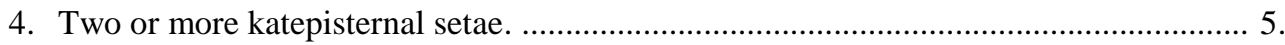

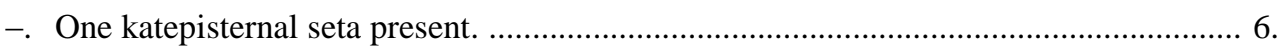

5. Proepisternal seta absent, two katepisternal setae, mid tibia without posterodorsal setulae. Electroleria HENNIG, 1965.

-. Proepisternal seta present, three katepisternal setae, mid tibia setulose posterodorsally. . Chaetohelomyza HENNIG, 1965.

6. Subcostal cell ending behind the level of anterior cross-vein, no proepimeral seta.

Heteromyza FALLÉN, 1820.

-. Subcostal cell ending at the level of anterior cross-vein, proepimeral seta welldeveloped. Balticoleria WoźNICA, 2007.

7. Two proepisternal setae, four pairs of dorsocentral setae present only.

Protoorbellia WoŹNICA 2006.

-. One proepisternal seta, more than five pairs of dorsocentral setae. 8 .

8. Anepisternum bare, scapular seta absent, gena distinctly projected.

Gedanoleria WoźNICA gen. nov.

-. Anepisternum setulose, scapular seta present, gena not projected.

Paleoheleomyza WOŹNICA \& PALACZYK, 2005.

\section{ACKNOWLEDGEMENTS}

I am very grateful to Christel and Hans HofFEINS (Hamburg, Germany) for making the specimen available for the present study and to Dr Krzysztof KsIĄżKIEWICZ (Wrocław) for his assistance in preparing the photograph. Also, I wish to express my appreciation to Prof. Ryszard SzADZIEWSKI (Gdańsk) for all his valuable comments and insights during the preparation of the manuscript. 


\section{REFERENCES}

Cumming J.M., Wood D.M. 2017. Adult morphology and terminology. [in:] A.H. KIRK-SpRIGGS, B.J. SinClAIR (Eds.). Manual of Afrotropical Diptera: Volume 1. SANBI Publications, Pretoria, 89-133.

Evenhuis N.L. 1994. Catalogue of the fossil flies of the World (Insecta: Diptera). Backhuis Publishers, Leiden.

Evenhuis N.L. 2014. Family Heleomyzidae. [in:] Catalog of the fossil flies of the world (Insecta: Diptera) website. Internet: http://hbs.bishopmuseum.org/fossilcat/Heleomyzidae.htmlv (accessed on 30.10.2019)

GoRodKov K.B. 1972. A system of Holarctic Helomyzidae (Diptera, Acalyptrata). [in:] Lectures at the XXIII Annual Readings in Memory of N.A. Kholodkovsky, 2 April 1970. Nauka, Leningrad, 50-92. (in Russian)

GorodKov K.B. 1984. Family Heleomyzidae (Helomyzidae). [in:] Á. Soós, L. PAPP (Eds.). Catalogue of Palaearctic Diptera vol. 10. Akademiai Kiado, Budapest, 15-45.

HENNIG W. 1965. Die Acalyptratae des Baltischen Bernsteins und ihre Bedeutung für die Erforschung der phylogenetischen Entwicklung dieser Dipteren Gruppe. Stuttgarter Beiträge für Naturkunde, 145: 1-215.

McAlPINE D.K. 1985. The Australian genera of Heleomyzidae (Diptera: Schizophora) and a reclassification of the family into tribes. Records of the Australian Museum, 36 (5): 203-251.

Meunier F. 1904. Contribution à la faune des Helomyzinae de l'ambre de la Baltique. Feuille des Jeunes Naturalistes, 35: 21-27.

Meunier F. 1908. Sur quelques diptères (Muscinae, Ortalinae, Helomyzinae) du copal récent de Zanzibar. Annales de la Société Scientifique de Bruxelles (Mémoires), 32: 252-257.

Meunier F. 1910. Contribution à la faune des diptères du copal récent de Zanzibar, de Madagascar et d'Accra. Annales de la Société Scientifique de Bruxelles (Mémoires), 34: 140-148.

PAPP L. 1998. 3.41. Families of Heleomyzoidea. [in:] L. PAPP, B. DARVAS (Eds..) Contributions to a manual of Palaearctic Diptera (with special reference to flies of economic importance). Volume 3: higher Brachycera. Science Herald, Budapest, 425-455.

SzADZIEWSKI R. 1988. Biting midges (Diptera: Ceratopogonidae) from Baltic amber. Polish Journal of Entomology, 58 (1): 3-283.

Szadziewski R., Szwedo J., Sontag E. 2018. Fauna of the amber forest. [in:] R. Szadziewski, R. Pytlos, J. SzwEDO (Eds.). Baltic amber - treasure of the Bay of Gdańsk. Związek Miast i Gmin Morskich, Gdańsk, 38-75.

Tschirnhaus M., Hoffeins C. 2009. Fossil flies in Baltic amber - insights in the diversity of Tertiary Acalyptratae (Diptera, Schizophora), with new morphological characters and a key based on 1,000 collected inclusions. Denisia, 26: 171-212.

WoźNICA A.J. 2003. Two new synonyms of the Old World representatives of the genus Suillia RobinEAU-DeSvoidy, 1830 (Diptera: Heleomyzidae: Suilliinae). Polish Journal of Entomology, 72 (4): 349-357. 
WoźNICA A.J. 2006a. Protoorbellia hoffeinsorum gen. and sp. nov., a new heleomyzid genus and species of the tribe Orbellini GoRODKOv from Baltic amber (Diptera, Heleomyzidae). Annales Zoologici, 56 (1): 147-151.

WoźNICA A.J. 2006b. Three new species of the genus Suillia Robineau-Desvoidy, 1830 from the Neotropical Region (Diptera: Heleomyzidae). Annales Zoologici, 56 (4): 657-665.

WoźNICA A.J., PAlaczYK A. 2005. A new genus and species of Heleomyzidae (Diptera) from Baltic amber. Polish Journal of Entomology, 74 (3): 373-378.

WoźNICA A.J. 2007. Balticoleria michaeli, gen. et spec. nov. from Eocene Baltic amber (Diptera, Heleomyzidae). Genus, Suppl. 14: 83-88.

Received: 12 November 2019

Accepted: 18 November 2019 